Jenniliisa Salminen

\title{
Kuka tarvitsee ketä? Lasten ja aikuisten välinen suhde Vladislav Krapivinin monimutkaisissa maailmoissa
}

Kornelilla ei ollut mitään muuta kuin osoite. Ei varmuutta siitä, että Cezar olisi kotona, ei suunnitelmaa. Ei täsmällisiä ajatuksia. Vain syvällä istuva arka arvelu, että hän tarvitsi Cezaria enemmän kuin Cezar häntä... (Gusi-gusi, gaga-ga..., 229. $)^{1}$

1980-luvun puolivälin Englannissa Jacqueline Rose kirjoitti sittemmin lastenkirjallisuudentutkimuksen klassikoksi muodostuneen teoksensa The Case of Peter Pan or The Impossibility of Children's Fiction, jossa hän esitti aikuisten kirjoittavan lastenkirjallisuutta itseään varten, omia tarpeitaan täyttääkseen. Esimerkkiteoksena - tai pikemminkin esimerkkihahmona - hän käytti Peter Pania, johon liittyviä kysymyksiä hän tarkasteli erityisesti psykoanalyyttisista lähtökohdista. Rosen näkemyksiin on sittemmin suhtauduttu kriittisesti, mutta niiden esittämisen jälkeen lastenkirjallisuutta on enää hyvin vaikea tarkastella ottamatta huomioon myös lastenkirjallisuuden aikuisia lukijoita ja kirjoittajia. Samoihin aikoihin Neuvostoliitossa Vladislav Krapivin kirjoitti lasten fantasiakirjallisuutta, joka herättää samankaltaisia kysymyksiä: hänen 1980- ja 1990-luvuilla kirjoittamiensa fantasiaromaanien, erityisesti V glubine Velikogo Kristalla -sarjan lukijoille tulee monesti mieleen kysymys, onko teksti tarkoitettu lasten vai aikuisten luettavaksi vai onko se kenties kirjailijan omien lapsiin ja lapsuuteen liittyvien kysymysten työstämistä. Lapsuuden merkitys on esillä myös teosten tematiikassa: lasten ja aikuisten välistä suhdetta pohditaan niin lapsi- kuin aikuishenkilöidenkin näkökulmasta. Teemaa käsitellään myös teosten rakenteellisten elementtien, erityisesti niiden fantasiamaailmojen rakenteen tasolla.

Vladislav Krapivinia ei juuri tunneta Suomessa, eikä hänen teoksiaan ole käännetty muillekaan kielille niin paljon kuin hänen suosionsa Neuvostoliitossa ja Venäjällä antaisi olettaa. Vuonna 1938 syntynyt Krapivin on Venäjän tuotteliaimpia lastenkirjailijoita. Hän aloitti kirjoitustyönsä 1950-luvulla ja on jatkanut sitä viime vuosiin asti. Krapivinin kaunokirjalliseen tuotantoon kuuluu lastenromaaneja ja kertomuksia, joista useimpia voi luonnehtia seikkailu- tai fantasiaromaaneiksi. Niiden päähenkilöt ovat yleensä hieman toisella kymmenellä olevia poikia, joita elähdyttää toisaalta vapauden- ja seikkailunkaipuu, toisaalta korkeat moraaliset ideaalit sekä vankkumaton ystävyys ja lojaalius ystäviä kohtaan. Näille poikahahmoille on kriitikoiden ja lukijoiden keskuudessa vakiintunut oma nimityksensä, "Krapivinin pojat" (krapivinskie maltšiki). ${ }^{2}$ Jos Peter Pan oli viktoriaanisen brittikulttuurin jälkimainingeissa seilaava, viktoriaanista lapsi- 
ideaalia nostalgisoiva lapsihahmo, Krapivinin pojat puolestaan ovat neuvostovuosien synnyttämiä lapsihahmoja, jotka ilmentävät toisaalta neuvostoliittolaisen pioneerikulttuurin valoisia puolia, toisaalta neuvostoaikaa edeltäneiden seikkailu- ja poikakirjojen vapaudenkaipuuta. Krapivinilla on myös pitkä historia lasten kanssa toimimisesta erilaisissa järjestöissä ja kerhoissa, ja häntä pidetään usein aitona lasten tulkkina sekä lasten oikeuksien puolustajana (ks. esim. Hellman 2013, 541; Bogatyreva 1997, 242-243).

Yhtenä Krapivinin 1980-luvun teosten keskeisenä teemana on lasten ja aikuisten välinen suhde. Näiden suhteiden monimutkaisuudella on vastineensa teoksissa esiintyvien maailmojen rakenteessa: mitä mutkikkaampia suhteita kuvataan, sitä monimutkaisempia ovat myös teosten fantasiamaailmojen rakenteet. Olen valinnut tähän artikkeliin käsiteltäväksi kaksi aiheeltaan samankaltaista teoskokonaisuutta, joiden fantasiamaailmojen rakenteet eroavat merkittävästi toisistaan. Romaani Deti sinego flamingo ("Sinisen flamingon lapset”) ilmestyi vuonna 1981 Uralski sledopyt -lehdessä ja 1982 kirjana. V glubine Velikogo Kristalla ("Suuren Kristallin uumenissa") -pentalogian teokset puolestaan ilmestyivät vuosina 1988-1991; sarjalle ilmestyi vielä kaksi itsenäistä jatko-osaa vuosina 1991 ja 1992. Deti sinego flamingo ja V glubine Velikogo Kristalla kuuluvat temaattisesti samaan jatkumoon keskenään: niissä käsitellään aikuisten ja lasten välisiä monimutkaisia suhteita tavoilla, jotka poikkeavat aiemmasta. Varhaisemmassa neuvostolastenkirjallisuudessa lasten ja aikuisten välit oli kuvattu varsin yksiselitteisinä, kun taas Krapivinin 1980-luvun teoksissa nostetaan esiin niiden ongelmallisuus ja monitahoisuus. Teoksia yhdistää tapahtumien sijoittuminen fantasiamaailmoihin, jotka kuitenkin eroavat selvästi toisistaan. Deti sinego flamingo -romaanin fantasiamaailma on selvästi päähenkilön arkimaailmasta erottuva saari, kun taas vuosikymmenen lopulla ilmestyneen V glubine Velikogo Kristalla -sarjan maailma on multiversumi, "kristalli", jonka jokainen tahko muodostaa oman maailmansa. Tämän artikkelin tarkoituksena on osoittaa, miten kyseisissä teoksissa maailmojen rakenne korreloi teosten keskeisen teeman monitahoisuuden kanssa.

\section{Kenelle teksti on kirjoitettu?}

Käsitellessään Peter Panin näytelmäversiota Jacqueline Rose (1984, 33) kysyy, onko se näytelmä lapsia varten vai lapsuuden spektaakkeli aikuisia varten. Samaa voi kysyä esimerkiksi seuraavan Vladislav Krapivinin tekstikatkelman kohdalla, jossa aikuinen päähenkilö katsoo tapaamaansa kymmenenvuotiasta poikaa:

Hän ei ollut erityisen kaunis. Hyvin suuri suu ja kolmikulmainen pieni leuka, kapeat posket, nykerönenä. Ainoastaan hiukset olivat kauniit: vaaleat, melkein valkoiset ja karhean näköiset, tasaiseksi palloksi leikatut. Kuin valtava tuuhea voikukka. Vain päälaella tasaisesta kampauksesta törrötti kuriton, saksia pakenemaan onnistunut töyhtö. Mutta kasvoilta puuttui lapsille tyypillinen, silmää hivelevä pyöreys. Niillä ei ollut mitään yhteistä niiden mainioiden 
naamataulujen kanssa, joita Korneli oli työssään tottunut laittamaan onnellisille perheille tarkoitettuihin mainoksiin... (Gusi-gusi, ga-ga-ga..., 112-114.) $)^{3}$

Katkelmassa lapsen tehtävä on olla aikuisen katseen kohteena. Tekstin tasolla aikuinen mainosmies Korneli Glas katsoo Cezaria, tekee havaintoja ja arvioi pojan ulkonäköä oman lapsikäsityksensä perusteella. Cezar ei sovi sen enempää Kornelin idealisoituun käsitykseen kauniista lapsista kuin hänen työssään edistämäänsä kuvaan lapsista "mainioina naamatauluina”, joita voi hyödyntää mainoksissa. Lukijalle saattaa neuvostokontekstissa syntyä myös mielleyhtymiä lasten käyttöön propagandassa, millä pyrittiin eri aikoina toisaalta edistämään erilaisia poliittisia pyrkimyksiä, toisaalta luomaan kuvaa siitä, millaisia lasten pitäisi olla (ks. esim. Kelly 2007, 1-2, 93-94). Myös lukijan kannalta katkelma vaikuttaa ennemmin aikuisille kuin lapsille suunnatulta: aikuisen miehen näkökulmasta lasta tarkastelevan kertojan kuvaama "lapsille tyypillinen, silmää hivelevä pyöreys" ja "onnellisille perheille tarkoitetut mainokset" sisältävät tunnelatausta ja ironiaa, jotka tuntuvat puhuttelevan enemmän aikuista lukijaa kuin lasta.

Nykyään kirjallisuudentutkijat pitävät selvänä, että lastenkirjallisuus ei ole vain lapsille kirjoitettua. Lastenkirjallisuuden kahtalaista yleisöä on Suomessa tutkinut esimerkiksi Maria Laakso (2014) väitöskirjassaan. Lastenkirjallisuuden perinteisiin aikuislukijoihin kuuluvat "viran puolesta" lastenkirjallisuutta lukevat: lasten vanhemmat, opettajat, kirjastonhoitajat, kustantajat, kääntäjät, kriitikot ja niin edelleen. Viime aikoina on puhuttu paljon myös crossover-ilmiöstä, jossa aikuiset lukevat lastenkirjallisuutta itsensä eivätkä lasten takia (Falconer 2009, 7). Nimitys crossover fiction yhdistetään mediassa sellaisiin viime vuosien menestysteoksiin kuin J. K. Rowlingin Harry Potter -sarja (1997-2007), Suzanne Collinsin Nälkäpeli-sarja (2008-2010) ja Veronica Rothin Outolintu-sarja (2011-2013). Käsite on liitetty myös 2000-luvulla paljon huomiota saaneeseen kiddult-ilmiöön: aikuisiin, joilla on lapsille ja nuorille tyypillisinä pidettyjä harrastuksia (Falconer 2009, 32). Kuten Sandra Beckett (2009, 2) toteaa, kyseessä on kuitenkin varhaisempi ilmiö: lasten ja aikuisten lukutottumukset ovat jo kauan olleet osaksi päällekkäisiä. Beckett soveltaa termiä monenlaiseen kirjallisuuteen ja monenlaisiin kirjailijoihin: Harry Potterin kaltaiseen lastenkirjallisuuteen, jolla on paljon aikuislukijoita, alun perin aikuisille tarkoitettuihin teoksiin, kuten esimerkiksi Kolmeen muskettisoturiin, joita nykyään lukevat myös - tai jopa etupäässä - lapset ja erityisesti fantasiakirjallisuuden kohdalla teoksiin, jotka on alun perin tarkoitettu sekä aikuisille että lapsille. Hän soveltaa termiä myös sekä aikuisten- että lastenkirjallisuutta kirjoittaneisiin kirjailijoihin, kuten Juri Olešaan. Crossover-kirjallisuudesta puhuttaessa voidaan siis toisaalta tarkoittaa tiettyä sekä lapsille että aikuisille suunnattua genreä ja toisaalta ilmiötä, jossa lastenkirjallisuuden ja aikuisten kirjallisuuden rajat tavalla tai toisella hämärtyvät lukijoiden mielessä. 
Neuvostoliittolaisen kirjallisuuden yhteydessä ei voi puhua crossover-kirjallisuudesta genrenä siinä mielessä, että olisi ollut olemassa erillinen kirjallisuuden laji, jota olisi kirjoitettu ja markkinoitu määrätietoisesti sekä lapsille että aikuisille. Kaunokirjalliset teokset julkaistiin Neuvostoliitossa yksiselitteisesti joko aikuisille tai lapsille. Toki oli kirjallisuutta, joka ylitti ikärajat: esimerkiksi tieteiskirjallisuutta lukivat kaikenikäiset ja tietyt kirjallisuuden klassikot kuuluivat sekä aikuisten että lasten ja nuorten lukuvalikoimaan, mutta kyse oli ennemmin crossoverista ilmiönä kuin genrenä. Liikenne oli lähinnä yksisuuntaista: lapset lukivat alkujaan aikuisille kirjoitettuja teoksia, mutta toisin päin ilmiö ei juurikaan vaikuttanut. Crossover genrenä on kansainvälisestikin uusi ilmiö. Varsinaista crossover-kirjallisuutena julkaistua ja markkinoitua kirjallisuutta on ollut olemassa vasta viime vuosina.

Vladislav Krapivinin tuotanto lasketaan Venäjällä selvästi lastenkirjallisuudeksi. Hänen teoksensa ovat ilmestyneet lasten- ja nuortenlehdissä sekä yksiselitteisesti lapsille suunnattuina kirjaversioina. Niitä myös käsitellään kirjallisuushistorioissa nimenomaan lastenkirjallisuutena ja Krapivinia lastenkirjailijana (ks. esim. Hellman 2013, 541; Bogatyreva 1997, 242-245). Kuitenkin Krapivinin teokset vetoavat myös aikuisiin sekä lukijoina että kriitikkoina: esimerkiksi romaania $V$ notš bolšogo priliva analysoinut Tsymbalenko (2010) löytää teoksesta aiheen pohtia, miten myös aikuiset tarvitsevat satuja. Lukijoiden mieltymyksistä kertoo esimerkiksi se, että venäläisellä fantasian harrastajien Laboratorija fantastiki -sivuilla Krapivinin teokset määritellään ikäluokitukseltaan kaikenikäisille, kun taas esimerkiksi sellaiset venäläiset lasten fantasiaklassikot kuin Nikolai Nosovin Neznajka-kirjat ja Aleksandr Volkovin Volšebnik Izumrudnogo goroda luokitellaan yksiselitteisesti lastenkirjallisuudeksi (Laboratornaja stranitsa Vladislava Krapivina). Vastaavasti venäläisessä sosiaalisessa mediassa Krapivinille omistetuilla Vkontakte-sivuilla kirjailijan tuotannosta keskustelevat nimenomaan aikuiset toisaalta muistellen nostalgisesti lapsuutensa lukukokemuksia, toisaalta kertoen aikuisiällä luettujen Krapivinin kirjojen tuottamista elämyksistä (Vladislav Krapivin VKontakte). Voinee sanoa, että Krapivinin alun perin lastenkirjallisuutena julkaistut fantasiateokset edustavat lukijaprofiilinsa perusteella venäläistä crossover-kirjallisuutta, jota lukevat kaikenikäiset.

Barbara Wall on märitellyt lastenkirjallisuudella olevan kolme tapaa puhutella yleisöään. Yksinkertaisen puhuttelun (single address) kohteena on lapsilukija, kaksinkertaisen puhuttelun (double address) kohteena on välillä lapsi, välillä aikuinen ja kaksoispuhuttelun (dual address) kohteena on samanaikaisesti sekä lapsi- että aikuislukija. (Wall 1994, 35.) ${ }^{4}$ Jaottelua on arvosteltu sen epämääräisyyden, yleistävyyden ja arvottavuuden vuoksi (ks. esim. Laakso 2014, 46; Cheetham 2013). Krapivininkaan tekstien kohdalla ei liene mielekästä käyttää suoraan näitä termejä, erityisesti koska kaksinkertaisen puhuttelun ja kaksoispuhuttelun käsitteiden välinen ero on varsin tulkinnanvarainen ja rivien välistä voi lukea Wallin $(1994,35)$ arvottavan kaksoispuhut- 
telun kaksinkertaista puhuttelua korkeammalle. En koe artikkelin kysymyksenasettelun kannalta järkeväksi käsitellä yksityiskohtaisesti, mitkä aspektit tai yksittäiset kohdat Krapivinin teoksista on tarkoitettu lapsilukijalle, mitkä aikuislukijalle, mitkä molemmille ja mitkä kenties kirjailijan itsereflektion välineeksi. Kuitenkin Wallin jaottelu näyttää konkreettisesti, että lastenkirjallisuuden yleisö on monipuolinen ja että siinä, missä teos joiltain osin puhuttelee yhtä osayleisöän, toiselta osaltaan se voi puhutella aivan toisenlaista yleisöä. Krapivinin teoksista on helppo osoittaa sekä lapsilukijalle tarkoitettuja kohtia - esimerkiksi jännittävät seikkailukohtaukset ja eläytymiseen rohkaisevat lapsen tunnemaailman kuvaukset - että kohtia, jotka ovat ainakin lyhyellä aikavälillä merkityksettömiä lapsilukijalle. Krapivinin teoksissa esimerkiksi kuvataan aikuisen lapsuuteen kohdistuvaa nostalgiaa nimenomaan aikuisen henkilön näkökulmasta ja korostetaan aikuisten vastuuta lapsista tavalla, jonka voi olettaa olevan suunnattu teosta lukevalle aikuiselle. Tietysti nämä osuudet teoksista voi olla tarkoitettu myös sille aikuiselle, joka lapsilukijasta joskus kenties tulee, jolloin lapsi- ja aikuisyleisön välinen raja hämärtyy entisestään, koska sama konkreettinen lukija on yhtä aikaa sekä lapsi että tuleva aikuinen.

\section{Maailmojen rakenteet}

Vuonna 1981 Uralski sledopyt -lehdessä ja 1982 kirjana ilmestyneessä romaanissa Deti sinego flamingo käsitellään fantasiamaailmaan etäännytettynä vakavia aiheita: lapsen kuolemaa ja aikuisten lapsiin kohdistamaa vallankäyttöä. Niitä käsitellään lapsen näkökulmasta tarkastellen, millaisia tunteita ne lapsessa herättävät ja miten lapsi näitä tunteitaan käsittelee. V glubine Velikogo Kristalla -pentalogia koostuu romaaneista Vystrel s monitora (1988), Gusi-gusi, ga-ga-ga... (1989), Zastava na Jakornom Pole (1989), Krik petuha (1990) ja Belyi šarik matrosa Wilsona (1991). Samaan maailmaan sijoittuvat myös jatko-osat Skazki o rybakah i rybkah (1991; ilmestynyt myös nimellä Lunnaja ryba) ja Lotsman (1992). Sarjan ilmestyminen ajoittuu Neuvostoliiton hajoamisen vuosiin ja maailman monimutkaisuuden pohtimisen voi liittää myös neuvostoideologian mukaisen narratiivin murtumiseen. Kuten esimerkiksi Pekka Pesonen (2012, 45-46) kuvaa, 1980-luvun perestroikaproosa jatkoi 1950- ja 1960-lukujen suojasään aikana alkanutta ja 1960- ja 1970-lukujen pysähtyneisyyden kaudella hidastunutta tiukimmista neuvostokirjallisuuden dogmeista vapautumisen prosessia. Siinä missä kirjallisuuden yleensäkin oli nyt mahdollista käsitellä "kiellettyjä aiheita" aiempaa kriittisemmin, myös lastenkirjailija saattoi kirjoittaa lasten ja aikuisten välisistä suhteista uudessa valossa. V glubine Velikogo Kristalla -sarjassa näkyy myös perestroikakirjallisuudessa toistuva aihe, uusien ihanteiden etsiminen. Sarjan viimeisessä jatko-osassa päädytään peräti varhaisen kristinuskon lähteille: teos päättyy apokryfiksi nimettyyn lukuun, jossa merkitykselliseksi nousee lapsihahmoinen Kristus. 
Wallin mukaan teokset puhuttelevat lasta ja aikuista eri tavoilla. Krapivinin teoksissa yksi keskeinen puhuttelun tapa on teosten tapahtumapaikkana toimivan maailman rakenne. Väitän, että vaikka kaikista käsitellyistä teoksista löytyy niin lasta kuin aikuistakin puhuttelevia elementtejä, Deti sinego flamingo -teoksen binäärisen vastakkainasettelun varaan rakentuva kahden maailman rakenne tukee teoksen lukemista lastenkirjallisuutena, kun taas V glubine Velikogo Kristalla -sarjan monimutkainen, abstrakti multiversumi tukee teosten lukemista myös aikuisille tarkoitettuna crossoverkirjallisuutena. Multiversumi rinnastuu sanana universumiin: siinä missä universumilla tarkoitetaan yhtä yhtenäistä maailmankaikkeutta, multiversumilla tarkoitetaan monista erillisistä maailmankaikkeuksista muodostuvaa kokonaisuutta. Kahden maailman rakennetta on käytetty neuvostoliittolaisessa lastenkirjallisuudessa jo ennen Krapivinia selkeiden vastakkainasettelujen kuvaukseen ja rakentamiseen. Multiversumi maailman rakenteena taas antaa mahdollisuuden käsitellä abstrakteja monitahoisia kysymyksiä: esimerkiksi brittiläinen Diana Wynne Jones on käsitellyt multiversumiin sijoittuvissa lastenkirjoissaan vierauden ja mihinkään kuulumattomuuden tunnetta (Steinke 2013). Tarkoituksena ei ole väittää, että maailmojen rakenteen kompleksisuus olisi mitenkään ehdoton vedenjakaja sen suhteen, onko jokin teos lastenkirjallisuutta vai ei. Tarkoituksena ei myöskään ole väittää, etteikö lastenkirjallisuudessa voisi käsitellä monimutkaisia abstrakteja asioita tai että ne jäisivät lapsilukijoiden käsityskyvyn ulkopuolelle. Voinee kuitenkin olettaa, että mahdollisia aikuisia lukijoita vetävät puoleensa lastenkirjoista nimenomaan ne teokset, jotka käsittelevät monitahoisia aiheita.

Romaanissa Deti sinego flamingo on selkeä kahden maailman rakenne: ensimmäinen maailma, jossa päähenkilö elää, ja siitä selvästi erottuva toinen maailma, Dvid-niminen näkymätön saari. Fantasiamaailma on rakenteeltaan avoin, eli teoksen maailmojen välillä on yhteys (Nikolajeva 1988, 36). Mikä on vielä tärkeämpää, teos rakentuu kahden maailman periaatteelle, jossa teoksen maailmat eroavat toisistaan selvästi niin, että teoksen lähtökohtamaailma hahmottuu normaaliksi, tavalliseksi, todelliseksi maailmaksi ja toinen maailma tavalla tai toisella "toiseksi", vieraaksi ja fantastiseksi. Niin päähenkilöt kuin lukijatkin joutuvat pohtimaan sen suhdetta todellisuuteen: onko se teoksen todellisuudessa oikeasti olemassa vai onko se päähenkilön mielikuvitusta tai unta.

Neuvostoliittolaisessa lastenkirjallisuudessa tällaisilla kahden maailman fantasioilla on pitkä perinne. Niitä on käytetty erilaisten ideologioiden vastakkainasetteluun: esimerkiksi Vitali Gubarevin teoksessa Korolevstvo krivyh zerkal (1951, ”Vääristävien peilien kuningaskunta”) asetetaan propagandistisesti vastakkain sosialistinen ja feodaalis-kapitalistinen ideologia: teoksen lähtökohtamaailma kuvaa neuvostotodellisuutta ja fantasiamaailma puolestaan feodaalista, diktaattorin kaltaisen kuninkaan hallitsemaa yhteiskuntaa. Toisaalta samainen rakenne on mahdollistanut toiseen maailmaan etäännytetyn yhteiskuntakritiikin: kyseistä Gubarevin teosta voi lukea myös neuvosto- 
järjestelmään kohdistuvana, joko tarkoituksellisena tai lukijan lukutavasta kumpuavana kritiikkinä. (Salminen 2009, 158-164.) Kahden maailman rakennetta on käytetty myös suoraviivaisen didaktisena kasvatusvälineenä: esimerkiksi Irina Tokmakovan teoksessa Stšastlivo, Ivuškin! (1983; Onnea matkaan Ilmari!, 1992) pikkupoika oppii satumaailmassa, että vanhempiin voi aina luottaa eikä heidän päätöksiään pidä kyseenalaistaa (Salminen 2009, 30).

Fantasiamaailman elementti on siis neuvostoliittolaisessa lastenkirjallisuudessa toisaalta mahdollistanut vallalla olevan ideologian ja siihen liittyvien kasvatustavoitteiden tukemisen, toisaalta rohkaissut kriittiseen ajatteluun. Rakenne, jossa yksi maailmoista on ensisijainen ja toinen on sananmukaisesti "toinen", voi neuvostokirjallisuuden yhteydessä liittyä myös venäläiselle kulttuurille tyypilliseksi koettuun svoi-tšužoi -vastakkainasetteluun, jossa vastakkain asetetaan "oma ja vieras", "me ja muut". Ensisijainen maailma on sekä neuvostoliittolaisissa fantasiateoksissa että yleensäkin lasten fantasiakirjallisuudessa useimmiten sekä päähenkilön että lukijan näkökulmasta oma: se toimii kirjoitusajankohdan maailman lakien mukaan ja on tuttuudessaan arkipäiväinen. ${ }^{5}$ Toinen maailma taas on vieras. Siellä voivat päteä erilaiset luonnonlait: taikuus saattaa olla mahdollista ja siellä voi elää mielikuvitushahmoja lohikäärmeistä yksisarvisiin, haltijoista puhuviin eläimiin. Toisessa maailmassa voi myös vallita erilainen yhteiskuntajärjestys, mitä käytettiin neuvostofantasiassa sosialistisen ja kapitalistisen maailmankuvan vastakkainasettelun välineenä.

Tätä taustaa vasten Deti sinego flamingo -romaanin maailman voi odottaa yhdistyvän binääriseen vastakkainasetteluun perustuvan teeman käsittelyyn. Tarinan lähtökohtamaailma näyttäytyy normaalina, lähtökohtaisesti turvallisena ja arkisena todellisuutena, ja toinen maailma normaalista poikkeavana, vaarallisena maailmana, jossa lapsille tapahtuu pahoja asioita. Deti sinego flamingo -romaanin toinen maailma ei silti ole yksinkertainen tai yksiselitteinen. Sen suhdetta todellisuuteen pohditaan teoksessa moneen kertaan eikä maailmojen välinen raja ole ehdoton. Päähenkilö päätyy saarelle sieltä tulevan muukalaisen kyydissä soutuveneellä, ja myöhemmin hän lentää maailmojen välillä jättiläismäisen sinisen flamingon kyydissä ilman, että missään vaiheessa sen enempää päähenkilölle kuin lukijallekaan selviäisi, missä maailmojen välinen tarkka raja kulkee. Teoksessa käy ilmi, että saarelle pääsisi periaatteessa kuka tahansa ja että ainoastaan saaren näkymättömyys suojelee sitä ulkopuolisilta. Dvid ei myöskään ole erityisen maaginen maailma: muutamat luonnonlait ja ilmiöt poikkeavat todellisen maailman vastaavista, mutta perusvireeltään maailma on jokseenkin realistinen, joskin ulkoisesti hieman varhaisempaan aikakauteen sijoittuva kuin tarinan neuvostotodellisuus. ${ }^{6}$ Myöskään fantasiamaailmaan etäännytetty teema, lasten ja aikuisten välinen suhde, ei ole samalla tavalla yksiselitteinen kuin vaikkapa neuvostofantasian usein käsittelemä sosialismin ja kapitalismin välinen ideologinen vastakkainasettelu neuvostokirjallisuudessa oli. 
Dvidin saaren keskeisenä käyttöfunktiona on, että problemaattiseksi koettua aihetta, lasten ja aikuisten välistä konfliktia, pystytään käsittelemään fantasiamaailmaan etäännytettynä. ${ }^{7}$ Teos eroaakin neuvostofantasian valtavirrasta siten, että siinä missä neuvostolastenkirjallisuudessa usein korostuu didaktinen asioiden välisen suhteen osoittaminen, Krapivinin romaanissa ennemmin nostetaan ilmiöitä esille ja herätetään ajattelua.

V glubine Velikogo Kristalla -sarjan maailma on multiversumi. Sen kuvataan muistuttavan kristallia, jonka jokainen tahko muodostaa oman maailmansa. Maailmojen rakenne on avoin, sillä vaikka jokainen maailma on oma itsenäinen kokonaisuutensa, osa sarjan henkilöistä pystyy siirtymään maailmasta toiseen. Teosten tapahtumat keskittyvät muutamaan maailmaan, mutta romaanissa Krik petuha käy ilmi, että erilaisia maailmoja on olemassa lukematon määrä. Sarjan multiversumi eroaa Deti sinego flamingo -romaanin kahden maailman rakenteesta sikäli, että mikään sen maailmoista ei ole toisiin nähden ensisijainen. Tietenkin yksittäisissä teoksissa päähenkilön näkökulmasta se maailma, jossa tämä on syntynyt ja kasvanut, näyttäytyy jossain mielessä primäärinä maailmana, mutta koko sarjan näkökulmasta katsottuna kaikki maailmat ovat samanarvoisia. V glubine Velikogo Kristalla -sarjan maailmat muistuttavat kaikki enemmän tai vähemmän meidän tuntemaamme todellista maailmaa, ja lukijalle, joka lukee sarjaa teosten ilmestymisjärjestyksessä, ei kovin nopeasti selviä, mikä maailmoista - jos mikään - vastaa "meidän omaa maailmaamme". Myös teoksen aikarakenne on monimutkainen: aika kuluu eri maailmoissa eri tahtia ja henkilöt siirtyvät aikatasolta toiselle, joten teossarjan tapahtumien aikasuhteiden tarkka rekonstruoiminen vaatii lukijalta todellista keskittymistä ja haastaa pohtimaan. Tällainen rakenne ohjaa lukijan valitsemaan kyseenalaistavan lukutavan ja pakottaa lukijan katsomaan sekä maailman rakennetta että kenties myös teoksen teemoja monesta näkökulmasta.

Sarjassa käsitellään maailman rakennetta myös teeman tasolla. Teoksissa on useita henkilöitä, jotka selvittelevät maailmankaikkeuden kristallimaista rakennetta. Sarjan neljännessä osassa Krik petuha aikuiset tiedemiehet kiistelevät sekä keskenään että kirkonmiesten kanssa maailmankaikkeuden rakenteesta ja maailmasta toiseen siirtymisestä tieteellisin ja uskonnollisin termein, kun taas teoksen päähenkilö, vähän toisella kymmenellä oleva Vitka keksii lähes spontaanisti maailmojen välillä siirtymisen mahdollistavan "suoran siirtymisen":

Hän ei vielä tiennyt, että nämä unet olivat ensimmäinen merkki suoran siirtymisen mahdollisuudesta. Että pian hänen ruumiinsa solut ja hermot oppisivat valveillakin eikä vain unessa löytämään maailmankaikkeuden särmien välistä tilojen välisiä aukkoja ja että hän itse omasta tahdostaan pian heittäytyisi hirvittävän maailmasta toiseen lentämisen pelon valtaan. Pelon, jota ei voi voittaa ja johon ei voi tottua... (Krik petuha, 93. $)^{8}$

Vitka ei ole ainoa maailmojen välillä siirtyjä. Suurin osa siirtymään pystyvistä on lapsia. Jo sarjan ensimmäisessä osassa esitellään sana 'koivo' viittaamassa lapsiin, joilla 
on yliluonnollisia kykyjä kuten taito siirtyä maailmojen välillä. Nämä erityiset lapset nähdään kautta sarjan jonkinlaisina ihmiskunnan edelläkävijöinä, joiden toivotaan tulevaisuudessa mahdollistavan ihmiskunnan kehittymisen kohti täydellisempää muotoa.

\section{Lasten ja aikuisten välinen suhde}

Neuvostoliittolaiselle lastenkirjallisuudelle oli tyypillistä, että vanhempien - tai vanhempiin verrattavissa olevien muiden aikuisten kuten opettajien tai pioneeriohjaajien auktoriteettia ei kyseenalaistettu. Aikuisten ja lasten välillä ei kuvattu olevan konflikteja tai jos niitä kuvattiin, ne olivat ideologisesti motivoituja. Esimerkiksi Pavlik Morozov -legendaa vahvistavassa Vitali Gubarevin lastenkirjassa Pavlik Morozov (1947; suom. 1953) esimerkilliseksi kuvatun "Neuvostoliiton ensimmäisen pioneerin" Pavlik-pojan aikuiset vastustajat - viljaa kolhoosilta pimittävä isä ja Pavlikin murhaavat talonpojat esitetään ideologisesti arveluttavina, uusia aatteita vastustavina maalaisina, jolloin konflikti ei ole niinkään lapsen ja vanhemman kuin ideologioiden välinen. ${ }^{9}$ Lähtökohtaisesti Krapivin kirjoittaa tätä kirjoittamatonta sääntöä vastaan kaikissa tässä artikkelissa käsitellyissä teoksissaan, joskaan niissäkään kritiikki ei kohdistu suoraan vanhempiin vaan yleisemmin aikuisten maailman rakenteisiin. Krapivinin teosten taustalla voi nähdä jo pysähtyneisyyden kaudella aikuisten kirjallisuuteen ilmestyneen nuorisotematiikan (ks. esim. Rytkönen 2015, 581). Nuorisokapina aiheena ei kuitenkaan lastenkirjallisuudessa vakiintunut samalla tavalla kuin länsieurooppalaisessa ja pohjoisamerikkalaisessa nuortenkirjallisuudessa, jossa lasten kapinointi vanhempiaan vastaan tavalla tai toisella on pitkään ollut yksi nuortenkirjallisuuden kantavista voimista (Trites 2000, 55).

Deti sinego flamingo -romaanin keskeiset aikuiset ovat kaikki tavalla tai toisella pahoja tai epäluotettavia, ja he pyrkivät alistamaan lapset valtaansa. Dvidin saaren asukkaiden kurinalaisuus perustuu siihen, että heiltä otetaan luulot pois jo lapsena. Saarella on lasten kurissapitämiseksi tiukka koulukuri korttelivalvojineen ja lapsia rangaistaan rikkomuksista julkisissa kuritusnäytöksissä. Tarinan varsinainen konna on saaren hallitsija, joka esiintyy valepuvussa kaksoisroolissa: hän on samalla sekä saaren kuningas että kuninkaan neuvonantaja. Hallitsijan petollisuus näkyy siinä, miten hän omaa asemaansa pönkittääkseen ensin houkuttelee tarinan päḧhenkilön, 11-vuotiaan Ženjapojan, saarelle väärin perustein käymään tuhoon tuomittua taistelua hirviötä vastaan ja myöhemmin on auttavinaan poikaa karkaamaan vankilasta, mutta johdattaakin tämän teloituspaikalle, jolta Ženja onnistuu hädin tuskin pakenemaan. Toisenlaista epäluotettavaa aikuistyyppiä edustaa erakko, jonka elämänfilosofiaan kuuluu olla tekemättä sen enempää hyvää kuin pahaakaan. Myös hänen välinpitämättömyytensä on viedä Ženjalta hengen. Ainoa aidosti lasten puolella oleva aikuinen saarella on sininen flamingoemo, joka auttaa lapsia kuin omia poikasiaan. Positiivista voimaa tarinassa edustavat lapset. Ženja päätyy asumaan hylättyyn linnoitukseen aikuisia paenneen lapsijoukon kanssa, 
jonka keskuudesta hän löytää aitoa ystävyyttä ja solidaarisuutta. Tarina päättyy siihen, miten saaren lapset lopulta nousevat taisteluun saaren aikuisia valtiaita vastaan.

Kahden maailman rakenne toimii teoksessa suurennuslasin tapaan. Ženja törmää epämiellyttäviin aikuisiin myös omassa maailmassaan, mutta nämä tapaamiset ovat luonteeltaan arkisempia: linja-autossa Ženja kokee aikuisten suhtautuvan nuivasti isoon poikaan, joka vielä leikkii puumiekalla, ja puiston limonadikojussa myyjä suhtautuu Ženjaan ikävästi. Ristiriitaisempia tunteita pojassa herättävät naapurin hukkuneeksi oletetun pojan vanhemmat, joiden ilmestyminen naapuruston lasten leikkiä seuraamaan herättää lapsissa ja erityisesti tarinan näkökulmahahmona toimivassa Ženjassa aiheettomia ja pojalle käsittämättömiä syyllisyydentunteita. Dvidin saaren lapsia sortavat aikuiset ovat kuin suurennuslasin läpi tarkasteltuja oikean maailman aikuisia, joiden lapsiin kohdistamat vääryydet saavat saarella eeppiset mittasuhteet. Asetelma ei ole harvinainen ongelmakeskeisessä fantasiakirjallisuudessa, jossa lapsi joutuu fantasiamaailmassa kohtaamaan pelkonsa tai jonkin muun itseään vaivaavan ongelman (ks. esim. Swinfen 1984, 91). Fantasiamaailmassa ongelma saa suuremmat mittasuhteet ja konkreettisemman hahmon, jota vastaan voi "taistella" selvemmin kuin todellisuuden kenties arkisempia mutta olemukseltaan abstraktimpia vaikeuksia vastaan.

Samoin kuin V glubine Velikogo Kristalla -sarjassa maailmojen rakenne on monimutkaisempi, myös aikuisten rooli on monisyisempi kuin Deti sinego flamingo -romaanissa. Osa aikuisista esitetään pahoina ja kovasydämisinä lasten sortajina: esimerkiksi Zastava na Jakornom Pole -romaanissa koulun rehtori lavastaa Jožiki-pojan äidin kuoleman, jotta sen aiheuttama ahdistus pakottaisi Jožikin piilevät erityiskyvyt rehtorin edustaman organisaation käyttöön. Aikuiset aiheuttavat lapsille kärsimystä myös lähempänä lukijan arkea olevilla tavoilla: romaanissa Krik petuha Vitkan isä on muuttanut tekemään tiedemiehentyötään toiseen maailmaan, eikä poika voi viettää isänsä kanssa niin paljon aikaa kuin haluaisi. Toinen isättömyydestä kärsivä poika, Belyi šarik matrosa Wilsona -romaanin Wilson, joutuu tulemaan toimeen alkoholisoituneen ja arvaamattoman isäpuolen kanssa. Toisaalta tapahtumien taustalla vaikuttaa "komandoreiksi" nimitetty joukko oikeamielisiä aikuisia, joiden elämäntehtävänä on sen tarkemmin selittämättä jätetty "lasten suojeleminen". ${ }^{10}$ Myöskään lapsia ei sarjassa esitetä pelkästään myönteisessä valossa: koulukiusaaminen on sarjassa toistuva motiivi ja sarjan viimeisessä osassa päähenkilö Wilson on vähällä kuolla sadistisen poikajoukon kynsissä.

Aikuisten näkökulma tapahtumiin korostuu: heti sarjan alussa ensimmäinen näkökulmahenkilö on aikuinen. Kirjasarjan perusteellisimmin kuvattu aikuinen on toisen osan Gusi-gusi, ga-ga-ga ... päähenkilö mainosmies Korneli Glas, jonka näkökulmasta asioita tarkastellaan ja jonka ajatuksiin teoksessa uppoudutaan. Hän elää futuristisessa valtiossa, "Läntisessä federaatiossa”, mukavaa elämää kuten kaikki hänen tuttavapiirinsä ihmiset. Kansalaisia valvotaan istuttamalla kaikkiin rekisteröinti- ja valvontalaite 
"biologinen indeksi”. Valvonta ei kuitenkaan Kornelia huolestuta, ja indeksitöntä ihmistä tarkoittava sana "bezynda” on hänen käytössään haukkumasana. Teoksen kuvaama yhteiskunta saa dystopian piirteitä, kun Korneli tuomitaan kuolemaan liikennesääntöjen rikkomisesta. Kornelin teloitus epäonnistuu, mutta indeksin poistamisen jälkeen häntä ei ole enää yhteiskunnan silmissä olemassa. Mies päätyy uutta teloitusyritystä odotellessaan huolehtimaan vankilan yhteydessä olevassa koulukodissa asuvista indeksittömistä lapsista. Lasten kanssa työskennellessä Kornelin arvomaailma muuttuu. Hän kyseenalaistaa entisen, nyt merkityksettömältä tuntuvan elämänsä ja alkaa muistella kouluaikojaan ja erityisesti pitkäksi aikaa unohtunutta lapsuudenystäväänsä. Korneli löytää lopulta elämälleen uuden merkityksen päättäessään pelastaa yhteiskunnan ulkopuolelle tuomitut indeksittömät lapset viemällä heidät toiseen maailmaan, jonne hänen uudelleen tapaamansa lapsuudenystävä näyttää tien. Erityisen sankarilliseksi alun perin hieman koomisessa valossa kuvattu mainosmies muuttuu, kun hän vaarantaa henkensä pelastaakseen erityiseksi kokemansa pojan Cezarin. Teos päättyy Kornelin näennäiseen kuolemaan, mutta sarjan myöhemmissä osissa lukijalle paljastuu, että kaikkien todennäköisyyksien vastaisesti hän onkin selvinnyt hengissä ja hänestä on tullut legendaarinen lasten oikeuksia puolustava "komandor".

Gusi-gusi, ga-ga-ga ... -romaanin läpäisevänä teemana on lapsen merkitys aikuiselle. Lapsia kuvataan varsin pintapuolisesti: lapset eivät ole missään vaiheessa fokalisoijina vaan heidät nähdään aina Kornelin silmin ja heillä tuntuu olevan merkitystä vain Kornelin elämässä tapahtuvan muutoksen mahdollistajina. Kornelin elämä hahmottuu nimenomaan lasten ja lapsuuden kautta. Hänen elämänsä suuri trauma on kouluvuosiin ajoittuva petos, jolloin hän heikkona hetkenään jätti ystävänsä Albinin pulaan. Korneli muistaa Albinin erityisenä lapsena: tämä osasi nähdä toiseen maailmaan ja onnistui näyttämään siitä vilauksen myös Kornelille. Aikuinen Korneli tapaa papiksi ryhtyneen Albinin, pappisnimeltään isä Pjotrin, monen vuoden jälkeen ja joutuu todistamaan tämän väkivaltaista kuolemaa. Samalla kun isä Pjotr näyttää aikuiselle Kornelille hänen kauan sitten unohtamansa toisen maailman, Korneli saa Albin-pojan muiston ja pelastamiensa lasten kautta takaisin sen, minkä kokee lapsuuden myötä menettäneensä. Kantaessaan kuolleen ystävänsä ruumista Korneli näkee hänet jälleen lapsena: ”Pjotr oli kevyt kuin pieni poika. Kornelista tuntui, ettei hän kantanut isä Pjotria vaan pientä Albinia, joka oli nyrjäyttänyt nilkkansa järvenrannalla hypättyään alas haljenneesta hopeapajusta. Niin oli kerran käynyt." (Gusi-gusi, ga-ga-ga..., 226.) ${ }^{11}$

Kornelin ajatuksissa aikuinen isä Pjotr ja Albin-poika sulautuvat yhteen. Lapsuuden ja aikuisuuden rajat sekoittuvat muutenkin Krapivinin teossarjassa. Samat henkilöt esiintyvät eri kirjoissa milloin lapsina, milloin aikuisina: esimerkiksi sarjan ensimmäisen osan päähenkilö koulupoika Pavel esiintyy Krik petuha -teoksessa vanhana miehenä ja aikuisten elämästä kerrottaessa palataan usein takaumissa heidän lapsuuteensa. 
Lapsuuden käsite muuttuu entistä abstraktimmaksi, kun sarjan päättävässä Belyi šarik matrosa Wilsona -romaanissa kristalli Jaška, jonka on tarkoitus kasvaa aikuiseksi, valitsee kristallina elämisen sijaan ihmiselämän, muuttuu pikkupojaksi ja kasvaa lopulta maailmankaikkeuden kristallirakennetta tutkivaksi tiedemieheksi ja yhden Krik petuha -teoksen henkilön esi-isäksi.

\section{Lopuksi}

Krapivinin romaanit ovat voimakkaasti sidoksissa kirjoitusajankohtaansa. Vuonna 1981 ilmestynyt Deti sinego flamingo edustaa vielä pysähtyneisyyden ajan kirjallisuutta sikäli, että se käyttää neuvostofantasiaan juurtunutta kahden maailman rakennetta jyrkkien vastakkainasettelujen käsittelyn välineenä vaikka esittääkin aiemmasta neuvostolastenkirjallisuuden valtavirrasta poikkeavan käsityksen lasten ja aikuisten suhteesta. $V$ glubine Velikogo Kristalla taas on selvää perestroikaproosaa, jossa maailma esitetään moniarvoisena ja lasten ja aikuisten välinen suhde moniulotteisena. Teoksista kuultaa myös Catriona Kellyn $(2007,152)$ kuvaama 1980-luvulla neuvostointelligentsian piirissä yleistynyt ajattelutapa, joka yhdisti lapsuuden riippuvuuteen muista sekä sorron ja manipulaation kohteena olemiseen. Lapsuutta ei enää välttämättä nähty samanlaisessa idealisoidussa valossa kuin esimerkiksi stalininaikaisessa propagandassa, vaan lapsuudesta tuli ennemminkin metafora johtajistaan riippuvaisille aikuisille. Deti sinego flamingo onkin malliesimerkki lastenkirjasta, jota voi halutessaan lukea allegoriana autoritäärisestä hallinnosta ja sen vaikutuksista kansalaisiin, ovatpa nämä sitten lapsia tai aikuisia.

Deti sinego flamingo -romaani ja V glubine Velikogo Kristalla -sarja kuuluvat joka tapauksessa samaan temaattiseen jatkumoon, vaikka keskeinen teema näyttäytyykin teoksissa erilaisessa valossa. Siinä missä ensimmäisessä rakennetaan selvä lasten ja aikuisten välinen vastakkainasettelu, jossa aikuiset nähdään yksiselitteisesti lasten sortajina ja lapset voivat luottaa vain toisiinsa, toisessa lasten ja aikuisten välinen suhde perustuu molemminpuoliseen riippuvuuteen. Siinä lapset tarvitsevat aikuisia selvitäkseen elämässään: koulukodin indeksittömät lapset tarvitsevat Kornelia johdattamaan heidät uuteen maailmaan, Jožiki tarvitsee kuolleeksi luulemansa äidin takaisin ja Vitka kaipaa toiseen maailmaan muuttanutta isäänsä. Vastaavasti aikuiset tarvitsevat lapsia: Korneli löytää elämälleen tarkoituksen lasten pelastamisesta ja kautta sarjan erityiskykyjä omaavat lapset tuovat aikuisille toivoa paremmasta tulevaisuudesta. Koko sarjan mittaisena kaarena näkyy kuva lapsista eräänlaisina aikuisten vapahtajahahmoina. Sarjan alussa parantajankykyjä omaava Pavel poistaa kivun iäkkään miehen selästä ja sarjan lopullisesti päättävässä jatko-osassa vanha kuolemansairas kirjailija saa oppaakseen pikkupojan, jonka kanssa hän saa tilaisuuden pohtia elämän tarkoitusta. Teoksen loppuun liitetty apokryfiksi nimetty kertomus Jeesuksen lapsuudesta ikään kuin täydentää ajatusta 
lapsista ihmiskunnan pelastajina. Teossarjan perusteella näyttää siltä, että siinä missä Krapivin varhaisemmassa tuotannossaan rakensi pioneeri-ideologiasta kumpuavaa omaa, lapsuuden merkitystä korostavaa ideologiaansa, 1980-luvulla ja 1990-luvun alussa Neuvostoliiton romahtamisen aikoihin hän näyttää lukijoilleen mahdollisuuden valtavirtauskonnosta poikkeavaan elämänfilosofiaan, joka sekin perustuu hänen näkemykseensä lapsuudesta ihmistä elähdyttävänä voimana. "Krapivinin pojat" korkeine moraalisine ideaaleineen, loputtomine vapaudenkaipuineen ja vankkumattomine ystävyyssuhteineen eivät näyttäydy vain lapsilukijoille tarkoitettuina roolimalleina vaan tarjoavat myös aikuiselle lukijalle mahdollisuuksia muistella nostalgisesti omaa lapsuuttaan tai löytää lasten kautta uusia merkityksiä omalle elämälleen. Teosten multiversumi heijastelee niiden monisyistä lapsi- ja aikuiskäsitystä. Aivan kuin maailmojen moninaisuudesta ei voi valita yhtä muita todempaa maailmaa, myöskään teoksen henkilöistä ei voi valita sen enempää päähenkilöä kuin sitä, kuka lopulta on aikuinen ja kuka lapsi.

\section{Viitteet}

${ }^{1}$ «Ничего, кроме адреса, у Корнелия не было. Ни уверенности, что Цезарь дома, ни планов. Ни точных мыслей. Только глубоко сидящая боязливая догадка, что Цезарь нужен ему, Корнелию, пожалуй, больше, чем он Цезарю...» (Gusi-gusi, ga-ga-ga..., 229.) Kaikki artikkelin suomennokset ovat kirjoittajan, J.S.

${ }^{2}$ Krapivinin teoksissa keskeiset lapsihahmot ovat yleensä poikia. Tyttöjäkin teoksissa esiintyy, mutta lähinnä sivuhenkilöinä ja päähenkilöitä tukevina hahmoina.

3 «Он был некрасив. Очень большой рот и треугольный маленький подбородок, твердые скулы, сильно вздернутый нос. Аишь волосы хороши - светлые, почти белые, и, видимо, жесткие, они были подстрижены ровным шаром. Как густой громадный одуванчик. И только на темени из ровной стрижки торчал непослушный,

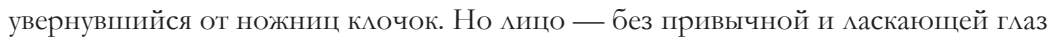
Аетской округлости. Ничего общего с теми славными мордашками, которые Корнелий на работе привык впечатывать в рекламные проспекты Аля счастливых семейств...» (Gusi-gusi, ga-ga-ga..., 112-114.)

${ }^{4}$ Termien suomennokset eivät ole ehdottomasti vakiintuneet. Olen käyttänyt Maria Laakson (2014, 45) väitöskirjassaan esittelemiä käännöksiä.

${ }^{5}$ Ensimmäisen maailman tuttuus ja arkipäiväisyys tosin pätee varmimmin kirjoittajan omasta kulttuuripiiristä peräisin oleviin aikalaislukijoihin. Esimerkiksi C. S. Lewisin Narniasarjan (1949-1954) lähtökohtamaailmana toimiva sodanjälkeinen Englanti kartanoineen ja sisäoppilaitoksineen lienee vaikkapa suomalaisille nykylukijoille varsin eksoottinen paikka. L. Frank Baumin The Wonderful Wizard of Oz-romaanin (1900) venäläisversion, Aleksandr Volkovin Volsebnik Izumrudnogo goroda (1939) Kansasin maaseudun tuttuutta neuvostoliittolaisille lapsilukijoille on pohtinut Maria Nikolajeva (2000, 63-64; ks. myös alaviite 1 s. 85). Kuitenkin kahden maailman rakenteelle perustuvissa teoksissa lukijalle käy yleensä kulttuuripiiristä riippumatta yksiselitteisen selväksi, kumpi teoksen maailmoista on tarkoitettu "todelliseksi maailmaksi” ja kumpi fantasiamaailmaksi.

${ }^{6}$ Fantasiamaailmat muistuttavat usein keskiaikaisia feodaalijärjestelmään perustuvia Euroopan 
maita. Myös Deti sinego flamingo -romaanin maailmalla on historiaan viittaavia piirteitä, mutta teknologioineen se muistuttaa hengeltään samoihin aikoihin suosituksi tulleita steampunkmaailmoita.

${ }^{7}$ Samoin toiseen maailmaan etäännytettynä käsitellään toista neuvostokirjallisuudessa vaikeaa aihetta: lapsen kuolemaa (ks. Salminen 2005).

8 «Он не знал еще, что эти сны — первый сигнац о возможности прямого перехода. Что скоро клетки его тела, его нервы не во сне, а наяву научатся отыскивать среди граней мироздания межпространственные щели и он уже сам, добровольно, будет кидаться в этот страх чудовищного полета из одного мира в Аругой. В страх, от которого нельзя избавиться и к которому нельзя привыкнуть...» (Krik petuha, 93.)

${ }^{9}$ Pavlik Morozovin tarina oli neuvostoideologialle tärkeä legenda, jonka todenperäisyyden ovat tutkimuksissaan kyseenalaistaneet ja suurimmaksi osaksi kumonneet Juri Družnikov (1988) ja Catriona Kelly (2005).

${ }^{10}$ Komandor on myös kirjailija Krapivinista useissa yhteyksissä käytetty lempinimi.

${ }^{11}$ «Петр был мегкий, как мальчишка. И Корнелию представилось, что несет не настоятеля Петра, а маленького Альбина, который подвернул ногу, прыгая с расщепленной ветлы на берегу озера. Так было однажды.» (Gusi-gusi, ga-ga-ga..., 226.)

\section{Kirjallisuus}

\section{Primäärilähteet}

Krapivin Vladimir 1985 (1982). Deti sinego flamingo. V. P. Krapivin, Vsadniki na stantsii rosa. Kišinjov: Lumina 252-377.

Krapivin Vladimir 2002 (1988). Vystrel s monitora. Moskva: Tsentropoligraf. Krapivin Vladimir 2002 (1989). Gusi-gusi, ga-ga-ga... Moskva: Tsentropoligraf. Krapivin Vladimir 1990. Zastava na Jakornom Pole. Pioner 1-2.

Krapivin Vladimir 2002 (1990). Krik petuha. Moskva: Tsentropoligraf.

Krapivin Vladimir (1991). Belyi šarik matrosa Wilsona. Uralski sledopyt 6-8.

Krapivin Vladimir 1991. Skazki o rybakah i rybkah. http://www.rusf.ru/vk/book/ skazki_o_rybakah_i_rybkah/main.htm (9.10.2016).

Krapivin Vladimir 1992. Lotsman. Uralski sledopyt 1-3.

\section{Sekundäärilähteet}

Beckett, Sandra L. 2009. Crossover Fiction : Global and Historical Perspectives. New York: Routledge.

Bogatyreva, N. Ju. 1997. Vladislav Krapivin. Russkie detskie pisateli XX veka: biobibliografiť̌eski slovar. Moskva: Flinta. Nauka.

Cheetham, Dominic 2013. Audience in Children's Literature. English Literature and Language 49, 19-30.

Družnikov, Juri 1988. Voznesenie Pavlika Morozova - The Myth of Pavlik Morozov. London: Overseas Publications Interchange Ltd. 
Falconer, Rachel 2009. The Crossover Novel: Contemporary Children's Fiction and Its Adult Readership. Routledge: London, New York.

Hellman, Ben 2013. Fairy Tales and True Stories: The History of Russian Literature for Children and Young People (1574-2010). Boston: Brill.

Kelly, Catriona 2005. Comrade Pavlik. The Rise and Fall of a Soviet Boy Hero. London: Granta Books.

Kelly, Catriona 2007. Children's World: Growing Up in Russia 1890 - 1991. New Haven and London: Yale University Press.

Laakso, Maria 2014. Nonsensesta parodiaan, ironiasta kielipeleihin. Monitasoinen huumori ja kaksoisyleisön puhuttelu Kari Hotakaisen Lastenkirjassa, Ritvassa ja Satukirjassa. Tampere University Press. http://urn.fi/URN:ISBN:978-951-44-9347-8 (5.9.2016).

Laboratornaja stranitsa Vladislava Krapivina, Laboratorija fantastiki. https://fantlab.ru/autor359 (10.5.2016).

Nikolajeva, Maria 1988. The Magic Code. The Use of Magical Patterns in Fantasy for Children. Stockholm: Almqvist \& Wiksell International.

Nikolajeva, Maria 2000. From Mythic to Linear. Time in Children's Literature. Boston: Scarecrow Press.

Pesonen, Pekka 2012. Perestroikaproosa. Tomi Huttunen \& Tintti Klapuri (toim.), Kenen aika? Esseitä venäläisestä nykykirjallisuudesta. Helsinki: BTJ Finland Oy, 45-61.

Rose, Jacqueline 1984. The Case of Peter Pan: or the Impossibility of Children's Fiction. London: Macmillan.

Rytkönen, Marja 2015 (2011). Pysähtyneisyydestä perestroikaan: 1960-1990. Kirsti Ekonen \& Sanna Turoma (toim.), Venäläisen kirjallisuuden historia. Helsinki: Gaudeamus, 567-629.

Salminen, Jenniliisa 2005. A Problematic Topic in a Totalitarian System - discussing the Death of a Child in Vladislav Krapivin's "Children of the Blue Flamingo". Jean Webb \& Mare Müürsepp (eds.), Sunny Side of Darkness: Children's Literature in Totalitarian and Post-Totalitarian Eastern Europe. Tallinn: TLÜ kirjastus, 165178.

Salminen, Jenniliisa 2009. Fantastic in Form, Ambiguous in Content: Secondary Worlds in Soviet Children's Fantasy Fiction. Sarja B. Humaniora, osa 317. Turku: Turun yliopisto. http://urn.fi/URN:ISBN:978-951-29-3805-6 (5.9.2016).

Steinke, Gabriela 2013. Moving Between Worlds: Foreignness in Diana Wynne Jones' Multiverse. Montserrat Cots, Pere Gifra-Adroher, Glyn Hambrook (eds.), Interrogating Gazes. Comparative Critical Views on the Representation of Foreignness and Otherness. Bern: Peter Lang, 261-268. 
Swinfen, Ann 1984. In Defence of Fantasy. A Study of the Genre in English and American Literature since 1945. London: Routledge \& Kegan Paul.

Trites, Roberta Seelinger 2000. Disturbing the Universe. Power and Repression in Adolescent Literature. Iowa City: University of Iowa Press.

Tsymbalenko, S. 2010 (1977). Zatšem nužna skazka? Zametki o novoi povesti Vladislava Krapivina. Per. v. el. vid Ju. Zubakin. http://www.fandom.ru/about_fan/ tsymbalenko_1.htm (10.5.2016).

Vladislav Krapivin VKontakte. http://vk.com/vladislavkrapivin (29.5.2016).

Wall, Barbara 1994 (1991). The Narrator's Voice. The Dilemma of Children's Fiction. Houndmills, Basingstoke, Hampshire and London: Macmillan. 